\title{
REORIENTASI PENGUATAN KEKUASAAN KEHAKIMAN MELALUI INDEPENDENSI KOMISI YUDISIAL
}

\author{
Noor Tri Hastutik \\ Fakultas Hukum \\ Universitas Wijaya Kusuma Surabaya
}

Abstrak

Reorientasi penguatan kekuasaan kehakiman melalui independensi komisi yudisial mengurai dan menjelaskan persoalan penguatan fungsi pengawasan kepada aktor utama penegakan wibawa hukum dan keadilan. Komisi Yudisial yang lahir melalui amandemen UUD 1945 adalah lembaga negara yang independen, memiliki fungsi dan wewenang pengawasan terhadap hakim.

Komisi Yudisial secara kelembagaan memang independen, tetapi fungsi wewenang dan tugas pokoknya lebih pada persoalan wilayah penjagaan citra kehormatan dan perilaku hakim, yang justru persoalan inti dari pengawasan yang secara filsofis paradigmatis perlu selalu diupayakan oleh seluruh lembaga pelaku dalam penegakan hukum bahkan oleh setiap pejabat, lembaga negara juga masyarakat.

Komisi yudisial dibentuk sebagai diskursus dari pemikiran fungsi pengawasan yang sebenarnya bagian dari kewenangan di Mahkamah Agung untuk melakukannya. Persoalan pengawasan intern terhadap hakim yang dulu dilakukan oleh eksekutif/pemerintah (melalui departemen kehakiman) adalah merupakan pemotongan wewenang kekuasaan yudisial oleh pemerintah orde baru. Kemudia melalui UU MA segala fungsi dan Wewenang yang memberikan jaminan independensi MA dikembalikan, akan tetapi fungsi pengawasan ini sudah lemah sejak masih ketika berada di tangan eksekutif.

Kata Kunci: Reorientasi, Kekuasaan Kehakiman, Independensi, Komisi Yudisial

\begin{abstract}
Reorientation of strengthening the independence of judicial power through the judicial commission to parse and explain issues to the strengthening of the oversight function main actors of law and justice enforcement authority. Judicial Commission that was born through the 1945 amendment is an independent state institution, has the function of supervision and authority of the judge. Institutionally Judicial Commission is independent but functions substantially more authority and duty to question the image of the honor guard and the behavior of judges, just the core issues of oversight that philosophically paradigmatic should always try by all actors in the law enforcement agencies and even by any officials, state agencies community as well. Judicial Commission of mind discourse dibentuksebagai actual function of this part of the supervisory authority in the Supreme Court to do so. Internal control issues to the judge who once performed by the executive I government (through the Justice Department) is the authorized withholding judicial power by the government of the new order. Then through the Supreme Court Act all the functions and authority that guarantees MA indepensi restored, but the oversight function has been weakened since died while in the hands of the executive.
\end{abstract}

Key words: judicial authorities, Independence, Judicial Commission

Reorientasi Penguatan Kekuasaan Kehakiman

Melalui Independensi Komisi Yudisial 
PENDAHULUAN

Laporan Komisi Ombudsman Nasional (KON) tahun 2002 berkenaan dengan pengaduan masyarakat berkaitan dengan penyimpangan yang terjadi di lembaga peradilan menempati urutan pertama (45\%) dibandingkan dengan lembaga lain. Bahkan laporan tahunan yang dikeluarkan KON tahun 2003 juga tidak mengalami banyak perubahan. Sebanyak 1121 laporan masyarakat, persentase terbesar pengaduan masyarakat ada pada lembaga peradilan sebesar 347 (31\%) dilanjutkan dengan kepolisian 212 (19\%), pemerintah daerah 168 (15\%) dan kejaksaan 100 (9\%). Laporan KON ini hanya salah satu dari sekian banyak persoalan yang menstigma rapuhnya peradilan di Indonesia. Wajah buram yudicial corruption, proses peradilan yang bisa diperjualbelikan, dan lain-lain telah mencoreng wajah keadilan lembaga peradilan. Lembaga peradilan sebagai penyelenggara kekuasaan yudikatif secara konsepsional dan konstitusional dalam prinsip negara hukum demokrasi adalah lembaga yan bebas dan merdeka dari campur tangan kekuasaan negara lainnya. Prinsip ini seharusnya menjadi sandaran yang kuat dan kokoh bagi lembaga peradilan untuk me-nyelenggarakan peradilan yang bersih, jujur dan adil dan bahkan tidak sebaliknya. (Sirajuddin, Zulkarnain, Sugianto, 2007;10-11)

Reorientasi Penguatan Kekuasaan Kehakiman Melalui Independensi Komisi Yudisial
Tuntutan reformasi, pasca 1998 diikuti dengan amandemen UUD 1945 membawa perubahan yang besar terhadap struktur ketatanegaraan Negara Republik Indonesia. Indonesia adalah Negara Hukum yang berpaham demokrasi. Dalam tradisi Negara demokrasi, dikenal tiga (3) pemegang kekuasaan negara, yakni pemegang kekuasaan pemerintahan (executive), pemegang kekuasaan perundang-undangan (legislative) serta pemegang kekuasaan kehakiman (yudicative).

Negara-negara yang berpahamkan demokrasi mengalami perkembangan yang sangat mendasar, bahwa pilar demokrasi tidaklah hanya bertumpu pada tiga pilar demokrasi, yaitu Trias Politika saja, namun ada kebutuhan untuk menyelenggarakan kekuasaan lainnya, yakni kekuasaan bidang perbantuan (state auxiliary institution/ organs state auxiliary) yang bersifat konsultatif, pertimbangan dan kepenasehatan (consultative power) dan kekuasaan Negara yang bersifat pengujian, penilaian dan pengawasan (examinative power). Pembentukan lembaga negara bantu dilakukan menurut dasar hukum yang berbeda. Komisi Yudisial dan Komisi Pemilihan Umum berdasarkan UUD 1945 hasil amandemen. Komnas HAM, Komisi Penyiaran Indonesia (KPI) dan Badan Perlindungan Konsumen Nasional (BPKN) berdasarNoor Tri Hartutik 
kan UU. Adapun Komisi Ombudsman Nasional dan Komisi Hukum Nasional (KHN) berdasarkan Keppres. Dibentuknya lembaga negara bantu ini adalah untuk menjawab tuntutan masyarakat agar penyelenggaraan pemerintahan negara melalui lembaga yang akuntabel, independen (bebas/ merdeka/mandiri) dan dapat dipercaya. Lembaga negara bantu bidang penyelenggaraan kekuasaan yudikatif, yang dibentuk dengan maksud untuk melakukan peningkatan effektivitas fungsi pengawasan di lingkungan peradilan. Mengapa perlu peningkatan effektivitas fungsi pengawasan di lingkungan peradilan yang senyatanya secara intern telah ada?. Saat ini di Indonesia, pengawasan di lingkungan peradilan dilakukan oleh Mahkamah Agung (MA), Komisi Yudisial (KY), dan Komisi Ombudsman Nasional. Di Kejaksaan ada komisi kejaksaan, dan di Kepolisian ada Komisi Kepolisian.

MA adalah pemegang kekuasaan kehakiman, sedangkan dalam pasal 32 UU No 14 Tahun 1985 jo UU No 5 Tahun 2004, lebih lanjut ditugaskan untuk melakukan pengawasan tertinggi atas penyelenggaraan peradilan di semua lingkungan peradilan serta melakukan pengawasan terhadap perilaku hakim di semua lingkungan peradilan. Hal ini haruslah dimaknai ,bahwa MA adalah pemegang "roh" dari citra pemilik kekuasaan kehakiman yang bebas dan berwibawa.

Perubahan ketiga UUD 1945 dilahirkan dua lembaga baru dalam kekuasaan kehakiman, yaitu Mahkamah Konstitusi dan Komisi Yudisial. Yang secara umum pembentukan dua lembaga baru ini, dimaksudkan untuk memperkuat kekuasaan kehakiman dalam sistem ketatanegaraan Indonesia sebagai salah satu perwujudan ketentuan UUD 1945 yang menyatakan bahwa Indonesia adalah negara hukum. Keberadaan Komisi Yudisial dalam struktur kekuasaan kehakiman mempunyai keterkaitan yang sangat erat dengan Mahkamah Agung. (Jimly Asshiddiqie, 2002;5) Apa makna dibalik pernyataan ini? Bahwa dalam pasal 24B UUD 1945 menyebutkan Komisi Yudisial merupakan lembaga negara yang bersifat mandiri dan berwenang mengusulkan hakim agung dan mempunyai wewenang lain dalam rangka menjaga dan menegakkan kehormatan, keluhuran martabat, serta perilaku hakim. Dengan demikian Komisi Yudisial memiliki dua kewenang -an yaitu: (a)mengusulkan pengangkatan calon hakim agung di Mahkamah Agung; (b)menegakkan kehormatan dan keluhuran martabat serta menjaga martabat serta menjaga perilaku para hakim di lingkungan Mahkamah Agung maupun di lingkungan Mahkamah Konstitusi. 
Komisi Yudisial ini dibentuk sebagai respon terhadap upaya penegakan dan reformasi di institusi peradilan, yang selama ini dinilai kurang baik. Selain itu, untuk meminimalisasi interest politik dari anggota DPR di dalam memilih dan menentukan hakim agung di Mahkamah Agung. Dalam kaitannya dengan hal ini, bahwa Mahkamah Agung adalah lembaga peradilan yang independen yang bebas, lepas dari campur tangan kekuasaan lain, obyektif serta dapat dipertanggung-jawabkan. Selama ini, pengawasan dilakukan terhadap internal peradilan oleh MA (lihat pasal 32 UU No 14 tahun 1985) dalam hal ini, terhadap para hakim yang terbukti melakukan pelanggaran, tetapi pengawasan ini kurang efektif untuk menindak secara tegas hakim-hakim yang melakukan pelanggaran tersebut. Di samping pengawasan oleh MA terhadap para hakim, Komisi Yudisial dibentuk untuk memberikan pengawasan terhadap perilaku hakim. Akan tetapi pelaksanaan wewenang Komisi Yudisial ini, sering dan banyak menemui kendala dan hambatan, yaitu dalam bentuk resistensi dari MA. Bahkan tidak atau belum adanya tindak lanjut dari pemeriksaan KY terhadap hakim yang diduga melakukan pelanggaran.

Fenomena ini menyisakan pernyataan, bahwa gambaran wajah buramnya peradilan, lalu memunculkan pertanyaan apakah dengan dibentuknya KY serta melalui KY akan dapat direposisikan pada citra lembaga yang luhur dan agung. Mengingat, hakim memiliki posisi yang paling penting di bidang penegakan hukum. Atau dalam bahasa yang umum, bahwa faktor yang paling strategis dan terpenting dalam penegakan hukum adalah terletak pada sumberdaya manusianya, yaitu hakim. Akan tetapi, justru ketika fungsi pengawasan internal di MA tidak berfungsi sebagaimana mestinya dan KY dibentuk, yang dimaksudkan untuk memberi penguatan pengawasan secara intern malah mendapat penghalang yang paling keras dari hakim itu sendiri (ingat! Ketika KY mempublikasikan namanama hakim agung yang ditengarai oleh masyarakat telah melakukan pelanggaran ternyata ditolak oleh MA dan bahkan ada beberapa hakim agung yang mengajukan uji materiil tentang kewenangan $\mathrm{KY}$, sehingga kewenangan $\mathrm{KY}$ terreduksi.(ibrahimsyah Amirudin, 2008; 48-49) ada apa? Bukan pada soal boleh tidaknya hakim agung melakukan uji materiil terhadap $\mathrm{MK}$, tetapi lebih pada fenomena, essensi kesiapan mental, moral hakim (hakim agung) untuk diawasi oleh institusi lain, walaupun $\mathrm{KY}$ masih dalam struktur kekuasaan kehakiman. Bukan telah ada suatu pernyataan: berikan kepada saya hakimhakim yang baik, niscaya kita akan 
mendapatkan penegakan hukum yang baik, walaupun hukum kita (baca peraturan) tidak/kurang baik. Dalam hal ini, otentisitas penegakan hukum lebih ditentukan oleh itikad yang otentik untuk menjalankannya. Bukankah dalam teori sosiologi hukum dikatakan bahwa hukum bukan hanya peraturan, tetapi juga perilaku (dan struktur sosial) (Esmi Warasih, 2005;67).

Dari uraian latar belakang tersebut di atas penulis mencoba menuangkan rumusan masalah adalah sebagai berikut: (1)Bagaimanakah independensi Komisi Yudisial terhadap Mahkamah Agung dan Mahkamah Konstitusi? (2)Apakah dan bila reorientasi penguatan Kekuasaan Kehakiman dapat dilakukan melalui Komisi Yudisial?

\section{Komisi Yudisial Sebuah Harapan: Tetap atau Sementara?}

Komisi Yudisial adalah lembaga baru yang dikenal setelah perubahan ketiga UUD 1945 dan termasuk dalam struktur kekuasaan kehakiman yang bersifat mandiri. Komisi Yudisial ini adalah lembaga negara (pasal 1 angka 1 jo pasal 2 UU No 22 Tahun 2004 tentang Komisi Yudisial).

Penamaan Komisi Yudisaial kepada lembaga negara baru ini, memunculkan suatu pertanyaan, apakah penamaan lembaga negara dengan kewenangan yang strategis, penting dan rawan menjadi pemicu konflik ini sudah tepat? Dan apakah pembentukan komisi yudisial dimaksud untuk menjadi lembaga negara yang memiliki bentuk tetap, mengingat fungsi pengawasan yang diwenangkan kepada komisi yudisial ini telah ada dan secara normatif telah diatur dalam UU MA. Walaupun secara ilmu norma, bahwa norma yang dicantumkan dalam sebuah konstitusi adalah norma yang dauerhaftig, apakah telah bisa ditetapkan bahwa Komisi Yudisial ini terus akan ada atau keberadaan KY hanya sebatas pada pada pencapaian pencitraan kewibawaan kekuasaan kehakiman. Ketika telah tercapai apakah KY akan dihapus, sehingga kelahiran KY tidak mereduksi kewenangan MA di bidang pengawasan. Kalaupun dimaksudkan sebagai lembaga yang hanya bersifat sementara (ad hoc), apakah pembentukan KY tepat diletakkan pada UUD? Sehingga KY merupakan sebuah lembaga yang ekstra konstitusional.

\section{Prinsip Independensi, Siapakah pengemban dan pengawal prinsip ini?}

Prasyarat pokok sistem di semua hukum modern atau modern constitutional state adalah prinsip dalam sistem peradilan, yang meliputi: a) the principle of judicial independence dan b) the principle of judicial impartiality. Prinsip independensi ini sendiri antara 
lain harus diwujudkan dalam sikap mental dan moral para hakim dalam memeriksa dan memutus perkara yang dihadapi. Independensi juga harus tercermin dalam pengaturan mengenai pengangkatan, masa kerja, pengembangan karir, sistem penggajian serta pemberhentian para hakim. Dan cerminan pengaturan tentang penunjukan/pengangkaan hakim dan aspek lain yang berkaitan dengan karir hakim telah ditempuh sebagai upaya penjaminan independensi hakim. (Bagir Manan, Kuntana Magnar, 1997;80-91). Ini semua akan menjadi indikator bahwa apakah pribadi hakim akan bekerja dan bertindak dengan berdasar dan bersandar pada prinsip ini. Dan prinsip ketidakberpihakan mengandung makna bahwa hakim tidak berpihak (to be impartial) dan tidak tampak berpihak (to appear to be impartial). Di samping itu, dalam The Banglore Principles ada enam prinsip yang harus dipedomani hakim, yaitu: (a)Independensi (Independence Principle); independensi hakim merupakan jaminan tegaknya hukum dan keadilan dan merupakan syarat bagi terwujudnya cita-cita negara hukum. Prinsip ini harus terimplementasi dan melekat secara mendalam dalam proses pemeriksaan, pengambilan keputusan atas setiap perkara yang merupakan roh dari citra Institusi yang berwibawa, bermartabat dan terpercaya, oleh karena itu, kemerdekaan hakim baik secara pribadi dan institusi haruslah wajib bebas dan menolak intervensi, paksaan, tekanan, kekerasan atau balasan dari kepentingan politik atau ekonomi dari pemerintah atau kepentingan kekuatan politik yang berkuasa; (b)Ketidakberpihakan (Impartiality Principle); mencakup sikap netral, hakim untuk menjaga jarak yang sama dengan semua pihak yang terkait dengan perkara dan tidak mengutamakan pihak manapun. Prinsip ini harus dihayati secara mendalam mengenai keseimbangan antar kepentinganyang terkait dengan perkara. Prinsip ini melekat dan harus tercermin dalam setiap tahapan proses pemeriksaan perkara sampai kepada tahap pengambilan keputusan, sehingga putusan pengadilan dapat benar-benar diterima sebagai solusi hukum yang adil bagi semua pihak yang berperkara dan oleh masyarakat luas pada umumnya. Oleh karena itu, prinsip ini melekat dengan fungsi hakim sebagai pihak yang diharapkan memberikan pemecahan masalah terhadap perkara yang diajukan kepadanya; (c)Integritas (Integrity Principle); merupakan sikap batin hakim yang mencerminkan keutuhan dan kseimbangan kepribadian setiap hakm secara pribadi dan sebagai pejabat Negara dalam menjalankan tugas jabatannya. Sikap ini meliputi: sikap jujur, setia dan tulus dalam menjalankan 
profesionalnya, disertai ketangguhan batin untuk menepis dan menolak segala bujuk rayu, godaan jabatan, kekayaan popularitas ataupun godaan-godaan lainnya. Sedangkan kseimbangan kepribadian mencakup kseimbangan rohani dan jasmani atau mental dan fisik, serta kseimbangan antara kecerdasan spiritual, kecerdasan emosional dan kecerdasan intelektual dalam pelaksanaan tugasnya; (d)Kepantasan dan sopan santun (Propriety principle); merupakan norma kesusilaan pribadi dan kesusilaan antar pribadi yang tercermin dalam perilaku setiap hakim, baik sebagai pribadi maupun sebagai pejabat negara dalam menjalankan tugas profesionalnya, yang menimbulkan rasa hormat, kewibawaan, dan kepercayaan. Kepantasan ini tercermin dalam penampilan dan perilaku pribadi yang berhubungan dengan kemampuan menempatkan diri dengan tepat, baik mengenai tempat, waktu, tata busana, tata suara, atau kegiatan tertentu. Sedang kesopanan terwujud dalam perilaku hormat dan tidak merendahkan orang lain dalam pergaulan antar pribadi, baik dalam tutur kata lisan maupun tulisan atau bahasa tubuh: dalam bertindak, bekerja, dan bertingkah laku: dalam bergaul dengan sesama hakim dengan karyawan atau pegawai pengadilan, dengan tamu, dengan pihak-pihak dalam persidangan atau pihak-pihak lain yang terkait dengan perkara; (e)Kesetaraan (Equality Principle); Kesetaraan merupakan prinsip yang menjamin perlakuan yang sama terhadap semua orang berdasarkan kemanusiaan yang adil dan beradab, tanpa membedakan satu dengan yang lain atas dasar agama, suku, ras, warna kulit, jenis kelamin, status perkawinan, kondisi fisik, status sosial ekonomi, umur, pandangan politik, atau alasanalasan lain yang serupa. Prinsip ini secara essensial melekat dalam sikap setiap hakim untuk senantiasa memperlakukan semua pihak dalam persidangan secara sama sesuai dengan kedudukannya masing-masing dalam proses peradilan; (f)Kecakapan dan keseksamaan (Competence and Diligence Principle); Kecakapan dan keseksamaan hakim merupakan prasyarat penting dalam pelaksanaan peradilan yang baik dan terpercaya. Kecakapan tercermin dalam ke-mampuan profesional hakim yang diperoleh dari pendidikan, pelatihan, dan/atau pengalaman dalam pelaksanaan tugas; sedangkan keseksamaan merupakan sikap pribadi hakim yang menggambarkan kecermatan, kehati-hatian, ketelitain, ketekunan, dan kesungguhan dalam pelaksanaan tugas profesional hakim.

Persoalan yang mendasar adalah bagaimana prinsip-prinsip ini disadari, diyakini, dihayati serta diwujudkan dalam sikap batin (Sjachran Basah, 
1992;5)dan tindakan hakim dalam menjalankan kehidupan pribadi dan profesinya. Kalau prinsip ini sudah menjadi roh kehidupan para hakim, maka citra kewibawaan, keluhuran martabat hukum akan terwujud melalui citra para hakimnya sebagai penjaga keadilan.

Prinsip yang telah dikomitmenkan oleh para hakim di belahan dunia ini, tentu saja bukan hanya ditulis sebagai hasil karya terindah dalam bidang hukum tetapi akan menjadi lebih dan semakin indah, bermakna dan memberikan kebahagiaan (bukankah hukum lahir atau dicipta untuk kebahagiaan manusia) karena diemban oleh orang-orang, yakni para hakim yang diinterplaykan dalam kehidupan pribadi dan profesinya. Para hakim sebagai pengemban prinsipprinsip interdependensi yang dimaksud tentu saja hakim di semua lingkungan peradilan serta hakim di Mahkamah Konstitusi (Pasal 24 ayat 2 UUD NRI Tahun 1945).

Pengembanan prinsip-prinsip interdependensi ini mengandung kekuatan ikatan batiniyah yang paling kuat sebagai tameng dan pencitraan yang paling kokoh. Akan tetapi, kurun waktu perjalanan sejarah penegakan hukum di Indonesia menunjukkan fluktuasi dan ritme yang berkecenderungan negatif. Oleh karena itu, pengembanan prinsipprinsip interdependensi ini, oleh pem- bentuk UUD negara ini perlu dilembagakan pengawasan, pebinaan atau perlu pengawalan secara mandiri dan bebas juga untuk secara bersama-sama mewujudkan kemandirian, kewibawaan serta keluhuran martabat kekuasaan kehakiman melalui para hakimnya.

\section{Reorientasi Penguatan Kekuasaan Kehakiman.}

Reorientasi dipahami sebagai kata yang terdiri dari kata "re" yang berarti kembali dan "orientasi" yang berarti peninjauan kembali untuk menentukan sikap/arah yang tepat dan benar. Atau dipahami sebagai pandangan yang mendasari pikiran, perhatian dan kecenderungan. (Balai pustaka Depdiknas, 2007;803)

Dalam hal ini, reorientasi dikonsepkan sebagai menentukan kembali cara pandangan/pikiran (paradigma) yang tepat, sesuai dan benar. Dalam kaitannya dengan penguatan kekuasaan kehakiman yang bebas dan mandiri, maka apakah mainset juga berlaku pada Komisi Yudisial yang secara normatif telah ditetapkan secara struktur masuk dalam kekuasaan kehakiman serta bagaimana peng-implementasiannya.

Menurut Jimly Asshiddiqie, Komisi Yudisial memang tidak menjalankan fungsi kekuasaan kehakiman, tetapi keberadaannya tidak bisa dipisahkan dari kekuasaan kehakiman. Keberadaannya terkait dengan jabatan 
hakim yang merupakan jabatan kehormatannya oleh suatu lembaga yang bersifat mandiri. Bagaimanakah karakter kemandirian KY? Suatu pertanyaan yang tentu saja tidak mudah untuk dijawab dan bukan hanya semata menjawab bersandar pada kaidah kaidah yang bersifat normatif belaka.

Berkenaan dengan status kelembagaan KY dalam struktur ketatanegaraan Indonesia, maka pertama kali kita harus melihat, hirarki norma / hirarki peraturan perundang-undangan di Indonesia. Masih menurut Jimly, bahwa hirarki peraturan perundang-undangan di Indonesia adalah sebagai berikut: (a)Peraturan Perundang-undangan yang bersifat umum: (1)Undang-Undang Dasar dan Perubahan Undang-Undang Dasar; (2)Undang-Undang dan Peraturan Pemerintah Pengganti UndangUndang serta peraturan lain yang setingkat Undang-Undang, yaitu Ketetapan MPR dan MPRS yang bersifat mengatur (regels); (3)Peraturan Pemerintah dan Peraturan Presiden; (4)Peraturan menteri atau Pejabat setingkat Menteri; (5)Peraturan Daerah Propinsi; (5) Peraturan Gubernur; (6)Peraturan Daerah Kabupaten/Kota; (7)Peraturan Bupati/ Walikota;(b) Peraturan perundangundangan yang bersifat khusus: (1)Peraturan Lembaga-Lembaga Negara (Lembaga Tinggi Negara) setingkat Presiden; (1.1)Peraturan Dewan Per- wakilan Rakyat; (1.2)Peraturan Dewan Perwakilan Daerah; (1.3)Peraturan Mahkamah Konstitusi; (1.4)Peraturan Mahkamah Agung; (1.5)Peraturan Komisi Yudisial; (1.6)Peraturan Badan Pemeiksa Keuangan; (2)Peraturan Lembaga Pemerintahan yang bersifat (Khusus) Independen; (2.1)Peraturan Bank Indonesia; (2.2)Peraturan Kejaksaan Agung;(2.3)Peraturan Tentara Nasional Indonesia; (2.4)Peraturan Kepolisian Indonesia; (3)Peraturan Lembaga Khusus yang bersifat Independen; (3.1)Peraturan Komisi Pemilihan Umum; (3.2)Peraturan Komisi Nasional Hak Asasi Manusia; (3.3)Peraturan Komisi Penyiaran Indonesia; (3.4)Dan lain-lain.

Menurut pengelompokan dalam hirarki peraturan perundang-undangan ini maka telah diketahui produk hukum KY adalah dikelompokkan dalam peraturan lembaga negara setingkat Presiden. Dengan demikian jelas, bahwa KY termasuk lembaga tinggi negara setingkat Presiden dan bukan lembaga pemerintahan yang bersifat khusus atau lembaga khusus yang bersifat independen yang dalam istilah lain disebut lembaga negara mandiri.

Dari sisi fungsi, bahwasanya KY dibentuk sebagai solusi dari latar belakang pembentukannya. Adapun halhal yang melatar belakangi pembentukan KY adalah sebagai berikut: (a)Lemah- 
nya monitoring secara intensif terhadap kekuasaan kehakiman, karena monitoring hanya dilakukan secara internal saja; (b)Tidak adanya lembaga yang menjadi penghubung antara kekuasaan pemerintah dalam hal ini Departemen Kehakman dan kekuasaan kehakiman; (c)Kekuasaan kehakiman dianggap tidak mempunyai effisiensi dan effektivitas yang memadai dalam menjalankan tugasnya apabila masih disibukan dengan persoalan-persoalan teknis -teknis non hukum; (d)Tidak adanya konsistensi putusan lembaga peradilan, karena setiap putusan kurang memperoleh penilaian dan pengawasan yang ketat dari sebuah lembaga khusus; (e)Pola rekruitmen hakim selama ini dianggap terlalu bias dengan masalah politik, karena lembaga yang mengusulkan dan merekrutnya adalah lembaga politik, yaitu presiden atau parlemen. Latar belakang pembentukannya ini menjadi dasar dari tujuan pembentukan KY yang meliputi: (a) Agar dapat memonitoring secara intensif terhadap kekuasaan kehakiman dengan cara melibatkan unsur-unsur masyarakat dalam spektrum yang selas-luasnya dan bukan hanya monitoring secara internal saja; (b)Menjadi perantara atau penghubung antara kekuasaan pemerintah dengan kekuasaan kehakiman yang tujuan utamanya adalah untuk menjamin kemandirian kekuasaan kehakiman dari pengaruh kekuasaan apapun juga, khususnya kekuasaan pemerintah; (c)Tingkat efisiensi dan effektivitas kekuasaan kehakiman akan semakin tinggi dalam banyak hal baik yang menyangkut rekrutmen dan monitoring hakim agung serta pengelolaan keuangan kekuasaan kehakiman; (d)Untuk menjaga kualitas dan konsistensi putusan lembaga peradilan, karena senantiasa diawasi secara intensif oleh lembaga yang benar-benar independen. Di sini diharapkan inkonsistensi putusan lembaga peradilan tidak terjadi lagi, karena setiap putusan akan memperoleh penilaian dan pengawasan yang ketat dari komisi yudisial. Dengan demikian, putusan-putusan yang dianggap kontroversial dan mencederai rasa keadilan masyarakat dapat dieliminasi; (e)Meminimalkan terjadinya politisasi terhadap rekruitmen hakim, karena lembaga yang mengusulkan adalah lembaga hukum yang bersifat mandiri, dan bebas dari pengaruh kekuasaan lain, bukan lembaga politik lagi, sehingga diidealkan kepentingankepentingan politik tidak ikut lagi menentukan rekrutmen hakim. Tujuan yang ditetapkan ini menjadi tantangan bagi KY yang akan dipertaruhkan reputasi kemandirian institusi maupun pribadi para anggotanya untuk menjalankan tugas yang sangat mulia ini. Sehingga suatu harapan baru tumbuh lewat KY, 
bahwasanya independensi KY akan jembatan untuk keluhuran martabat kekuasaan kehakiman melalui etos kerja, sikap batin dan sikap tindak para hakimnya. Semoga menjadi sebuah kenyataan.

\section{PENUTUP}

Dari uraian latar belakang serta pembahasan samapilah kiranya penulis pada bab simpulan. Adapun simpulan yang dapat disampaikan dalam tulisan ini adalah: Penguatan dan reorientasi penguatan kekuasaan kehakiman yang independen harus dinormatifkan dalam pengaturan melalui indikator cara pengangkatan hakim, penggajian dan hal-hal lain yang berhubungan dengan teknis non hukum untuk karir hakim. Dalam hal, pengawasan hakim secara internal maupun eksternal masyarakat bisa dilakukan melalui KY. Untuk pelaksanaan kewenangan KY sebagai lembaga negara setingkat Presiden, harus terlebih dahulu ada jaminan independensi anggota KY, kemudian KY penguatan independensi kekuasaan kehakiman baru dapat dilakukan.Oleh karena itu, independensi KY identik dengan independensi anggota $\mathrm{KY}$.

\section{DAFTAR PUSTAKA}

A Ahsin Thohari, (2004). Komisi Yudisial dan Reformasi Peradilan, ELSAM, Jakarta

Bagir Manan dan Kuntana Magnar (1997), Beberapa Masalah Hukum Tata Negara, Alumni, Bandung

Balai Pustaka-Depdiknas, (2007). Kamus Besar Bahasa Indonesia, Edisi Ketiga-Cet-IV, Jakarta

Ibrahimsyah Amirudin, (2008). Kedudukan KPU dalam Struktur Ketatanegaraan Republik Indonesia Pasca Amandemen UUD 1945, Laksbang Mediatama, Palangkaraya

Jimly Asshidiqie, (2007). Pokok-Pokok Hukum Tata Negara Indonesia Pasca Reformasi, Bhuana Ilmu Populer, Jakarta

Sirajudin-Zulkarnain-Sugianto, (2007). Komisi Pengawas Penegak Hukum- Mampukah Membawa Perubahan, MCW-YAPPIKA, Malang

Sjachran Basah, (1999). Perlindungan Sikap Tindak Administrasi Negara, Alumni, Bandung

Undang-Undang Dasar Negara Republik Indonesia Tahun 1945

Undang-Undang Republik Indonesia No. 22 Tahun 2004 tentang Komisi Yudisial

Undang-Undang Republik Indonesia No. 14 Tahun 1985 tentang Mahkamah Agung 
